\title{
Simulation of the acrylic acid production process through catalytic oxidation of gaseous propylene using ChemCAD $^{\circledR}$ simulator
}

\author{
Simulación del proceso de producción del ácido cítrico a través de la oxidación \\ catalítica del propileno gaseoso empleando el simulador ChemCAD®
}

\author{
Amaury Pérez Sánchez ${ }^{1}$ \\ Eddy Javier Pérez Sánchez ${ }^{2}$ \\ Rutdali María Segura Silva ${ }^{3}$
}

Recibido 8 de diciembre de 2016, aceptado 19 de marzo de 2018

Received: December 8, 2016 Accepted: March 19, 2018

\begin{abstract}
In the following study, the simulation of the polymeric-grade acrylic acid (AA) production process is carried out using the simulator ChemCAD ${ }^{\circledR}$ version 5.2.0., in order to obtain mass balance results in all the process streams and also to know the most important design parameters of the equipment used. Two sensitivity studies were carried out: 1) influence of the absorption tower operating temperature in the amount of AA obtained at the bottom column; and 2) influence of the recovery column working pressure in the amount of acetic acid obtained on it. At the recovery column a liquid bottom stream containing AA with $99.90 \%$ purity is obtained, while in the acids column the AA is obtained with $99.86 \%$ purity at the bottom stream. It's recommended that the absorption tower operates at a temperature near $20^{\circ} \mathrm{C}$, while the recovery column must run under vacuum conditions, in order to reduce both the AA and acetic acid losses.
\end{abstract}

Keywords: Acrylic acid, simulation, mass balance, equipment, propylene.

\section{RESUMEN}

En el siguiente trabajo se lleva a cabo la simulación del proceso de producción del ácido acrílico $(A A)$ polimérico empleando el simulador de procesos ChemCAD® versión 5.2.0, con el fin de obtener resultados de balance de masa en todas las corrientes de proceso, así como también para conocer los parámetros de diseño más importantes del equipamiento usado. Se llevaron a cabo dos estudios de sensibilidad: 1) influencia de la temperatura de operación de la torre de absorción en la cantidad de AA a obtener por el fondo de la columna, y 2) influencia de la presión de trabajo de la columna recuperadora sobre la cantidad de ácido acético a obtener en este equipo. Por el fondo de la columna recuperadora se obtiene una corriente líquida conteniendo AA con 99,90\% de pureza, mientras que en la columna de ácidos el AA se obtiene con una pureza del $99,86 \%$. Se recomienda que la torre de absorción opere a una temperatura cercana a los $20^{\circ} \mathrm{C}$, mientras que la columna recuperadora deberá operar bajo condiciones de vacío con el fin de reducir las pérdidas tanto de AA como de ácido acético.

Palabras clave: Ácido acrílico, simulación, balance de masa, equipamiento, propileno.

\footnotetext{
1 Universidad de Camagüey. Carretera Circunvalación Norte, Km. 51/2, e/ Camino Viejo de Nuevitas y Ave. Ignacio Agramonte. Camagüey, Cuba. CP 74 650. E- mail: amauryps@nauta.cu

2 Empresa Agroindustrial Ceballos. Carretera a Ceballos, Km. 12 1⁄2, Ciego de Ávila, Cuba. E-mail: eddy.perez@reduc.edu.cu

3 Centro de Ingeniería Genética y Biotecnología de Camagüey. Circunvalación Norte y Avenida Finlay. Apartado Postal 387. E-mail: ruthdaly.segura@cigb.edu.cu

* Corresponding Author
} 


\section{INTRODUCTION}

Acrylic acid $\left(\mathrm{CH}_{2}=\mathrm{CHCOOH}\right.$; melting point: 13.5 ${ }^{\circ} \mathrm{C}$; boiling point: $141{ }^{\circ} \mathrm{C}$; density: $1045 \mathrm{~g} / \mathrm{L}$ ) is a colorless liquid miscible in water, ethanol, benzene, chloroform and acetone [1]. It's currently produced in two commercial forms: technical ( 94\% purity) and glacial grade (98-99.5\% purity), and is used as the main raw material to obtain a wide range of useful products such as superabsorbent polymers, detergents, water treatment chemicals, adhesives, dispersants, sealants, paints, lubricants, surface coatings, plastic modifiers and oxidizing agents for textile industry [1-2].

It's obtained at industrial scale by means of several energy-intensive chemical processes [2-3], being the most important the following: 1) Catalytic hydration of acetylene in the presence of carbon dioxide, an alcohol and nickel carbonyl as the catalyst; and 2) Hydrolysis of acrylonitrile. However, the production process most used at present at commercial scale consists of the catalytic oxidation of gaseous propylene through the application of two process stages [2]:

Catalytic oxidation of propylene to acrolein:

$$
2 \mathrm{CH}_{2}=\mathrm{CHCH}_{3}+\mathrm{O}_{2} \rightarrow 2 \mathrm{CH}_{2}=\mathrm{CHCHO}+\mathrm{H}_{2} \mathrm{O}
$$

Catalytic oxidation of the acrolein to acrylic acid:

$$
2 \mathrm{CH}_{2}=\mathrm{CHCHO}+\mathrm{O}_{2} \rightarrow 2 \mathrm{CH}_{2}=\mathrm{CHCOOH}
$$

Process simulation and modeling is the application of a range of software tools to analyze individual unit operations (or process stages) and their relationships within the overall process. Process simulation is defined as the utilization of computer software resources to develop mathematical models for the construction of an accurate, representative model of a chemical process in order to understand its actual behavior during regular plant operations [4]. These tools can be used at all stages of process development, from conceptual design, through process operation and optimization.

The current trend in the industry is to use commercial process simulation suites or custom designed process simulators to simulate the large, complex and inter-connected industrial processes that represent an actual chemical plant. This ranges from small batch plants to large process chemical industries [5]. Among the simulators most used today are ASPEN Plus ${ }^{\circledR}$, SuperPro Designer ${ }^{\circledR}$, Prosim $^{\circledR}$, Aspen HYSYS ${ }^{\circledR}$ and ChemCAD ${ }^{\circledR}$ [6-7]. ChemCAD $^{\circledR}$ simulator has been used in several important chemical process applications such as the simulation of an acetaldehyde manufacturing plant, including equipment seizing and economic calculations [8]; the simulation of an olive pits fed rotary kiln pyrolysis plant [9]; simulation of the biodiesel production process by transesterification of vegetable oils [10]; optimization of complex chemical processes using stochastic algorithms [11]; modeling chemical reactors for simulation of a methanisation plant [12]; modeling the separation process of various valuable components from turpentine [13]; and the production of formaldehyde via Formox process [14].

Thus, process simulators offer the opportunity to shorten the time required for process development. They allow comparison of process alternatives on a consistent basis so that a large number of process ideas can be synthesized and analyzed interactively in a short time [15]. Simulation of integrated processes also enables the study of interactions that exist between upstream and downstream processes [16].

The present work deals with the conceptual design and simulation of an AA production plant capable of producing 5.5 tons of glacial-grade AA per batch through of gaseous propylene catalytic oxidation route. The process simulator ChemCAD ${ }^{\circledR}$ is used as the key tool in order to carry out mass and energy balances, as well as to determine the most important design parameters of the main equipment used. This will enable further optimization approaches in order to increase the efficiency and productivity of this production process. The plant will operate about 7200 hours per year under stationary continuous conditions, while acetic acid will be obtained as a high-value by product.

\section{MATERIALS AND METHODS}

\section{Production process description}

The first stage consists of mixing the following components: gaseous propylene, compressed air and low-pressure steam $\left(6.03 \mathrm{bar}, 159{ }^{\circ} \mathrm{C}\right)$ in a closed metallic vessel at the proportion $1 / 7.75 / 3.75$, to obtain a gaseous reacting mixture at $120{ }^{\circ} \mathrm{C}$ 
approximately. This mixture is fed then to a vertical, cylindrical, shell and tube reactor (Reactor 1), at which the gaseous mixture flows inside the tubes through the catalyst bed, while a cooling agent (brine) circulates in the shell at a controlled flow in order to regulate the reaction temperature in the $290-330^{\circ} \mathrm{C}$ range. The reaction temperature should not increase above $350^{\circ} \mathrm{C}$ in order to avoid catalyst calcination, thus affecting the acrolein production rate. A hot gaseous mixture, containing mostly acrolein, AA, acetic acid and water, is obtained at the top of the Reactor 1 and sent, as the feed stream, to the Reactor 2, which has a mechanical design similar to that of the Reactor 1. This reactor contains a specific solid catalyst $\left(\mathrm{Mo}_{12} \mathrm{~V}_{1.9} \mathrm{Al}_{1.0} \mathrm{Cu}_{2.2}\right)$ in order to produce the AA from the acrolein. The Reactor 2 must operate at $280-320^{\circ} \mathrm{C}$ to maintain an AA production yield of $85 \%$, approximately. It's very important to cool rapidly the hot gaseous mixture exiting at the top of the Reactor 2 to avoid the occurrence of secondary reactions that could affect the AA production yield, and increase its explosive properties over the maximum permissible limit. In that respect, this gaseous stream is cooled from $300{ }^{\circ} \mathrm{C}$ to $70{ }^{\circ} \mathrm{C}$ in a shell-and-tube heat exchanger using cooling water. Once cooled, a two-phase (vapor-liquid) stream is obtained at the exchanger exit, which is sent then to an absorption (flash) tower operating under countercurrent conditions, to be washed using deionized water (solvent) at a feed flowrate of $2540 \mathrm{~kg} / \mathrm{h}$. During this absorption operation, certain gaseous compounds, such as nitrogen, carbon dioxide, oxygen and propylene, as well as some traces of AA and acetic acid that were not absorbed by the solvent, are removed at the top and vented to the atmosphere. The pressure of the feed two-phase (vapor-liquid) stream is increased to 4.0 bar prior to enter the absorption tower via a pressure-regulating valve. The aqueous, relatively cold stream obtained at the column's bottom, which contains AA at a mass concentration of $18-25 \%$, is then sent to a liquid-liquid extraction column (extractor). The extractor is s tray column that uses di-isopropylether (DIE) as the solvent at a rate of 500 $\mathrm{kg} / \mathrm{h}$. The solvent is fed at the top of the extractor, while the aqueous mixture enters at the bottom, thus flowing countercurrent through the packed bed. A liquid mixture, containing mostly AA and acetic acid extracted by the solvent DIE, is obtained at the top of the extractor, while an aqueous stream is obtained at the bottom. The bottom stream is preheated in a shell-and-tube heat exchanger to a temperature of $95^{\circ} \mathrm{C}$, prior to being fed to a plate distillation column (residuals column), at which the solvent DIE is separated from the other components. In this equipment, the DIE is obtained at the top, and is recycled back to the extractor, while a liquid stream containing mostly water (aqueous residual stream) is obtained at the bottom and sent to the water treatment section.

The top stream obtained in the extractor is preheated in a shell-and-tube heat exchanger to a temperature of $85^{\circ} \mathrm{C}$, and then fed to the solvent recovery column (recovery column), a perforated-plate distillation column, to carry out the primary separation (purification) of the AA. In that case, near $95 \%$ of all the AA and acetic acid fed to this column is obtained at the bottom liquid stream, which is sent to the acids column, while the top stream contains mostly steam and the solvent DIE. The recovery column operates under vacuum conditions $(0.15$ bar). The acids column is a plate distillation tower that also operates under vacuum conditions, and in which the AA final purification step takes place. A water-acetic acid liquid mixture is obtained at the top of the acids column, while at the bottom a liquid stream containing about $99.0-99.5 \%$ of AA is obtained, which constitutes then the final product. Since the acrylic acid dimerizes easily at temperatures above $90{ }^{\circ} \mathrm{C}$ if present at high concentrations, it's recommended that all distillation operations must be carried out under vacuum conditions, while the final product obtained should be stored in ceramic-, aluminum- or glass-lined drums in a well-ventilated, cold and dry place.

\section{Catalysts}

Two types of catalysts will be used (Table 1). The first one will convert the propylene into acrolein, while the second will convert this acrolein into AA.

Table 1. Properties of the catalysts used. [17-19].

\begin{tabular}{|l|c|c|}
\hline \multicolumn{1}{|c|}{ Property } & Catalyst 1 & Catalyst 2 \\
\hline Type & $\begin{array}{c}\alpha-\mathrm{Bi}_{2} \mathrm{Mo}_{3} \mathrm{O}_{12} \\
\left(\mathrm{SiO}_{2} \text { inert }\right)\end{array}$ & $\begin{array}{c}\mathrm{VMo}_{3} \mathrm{O}_{11} \\
\left(\mathrm{SiO}_{2} \text { inert }\right)\end{array}$ \\
\hline Limit temperature $\left[{ }^{\circ} \mathrm{C}\right]$ & $350^{\circ} \mathrm{C}$ & $350{ }^{\circ} \mathrm{C}$ \\
\hline Particle diameter $[\mathrm{mm}]$ & 3 & 4 \\
\hline Particle density $\left[\mathrm{kg} / \mathrm{m}^{3}\right]$ & 1600 & 1480 \\
\hline Void fraction & 0.3 & 0.3 \\
\hline
\end{tabular}


Table 2. Chemical reactions occurring at Reactor 1.

\begin{tabular}{|c|c|}
\hline Reaction & Extent \\
\hline $\mathrm{C}_{3} \mathrm{H}_{6}+\mathrm{O}_{2} \rightarrow \mathrm{C}_{3} \mathrm{H}_{4} \mathrm{O}+\mathrm{H}_{2} \mathrm{O}$ & $79 \%$ \\
\hline $\begin{array}{c}\text { Acrolein formation: acid formation: } \\
\mathrm{C}_{3} \mathrm{H}_{6}+\frac{3}{2} \mathrm{O}_{2} \rightarrow \mathrm{C}_{3} \mathrm{H}_{4} \mathrm{O}_{2}+\mathrm{H}_{2} \mathrm{O}\end{array}$ & $6 \%$ \\
\hline $\mathrm{C}_{3} \mathrm{H}_{6}+\frac{5}{2} \mathrm{O}_{2} \rightarrow \mathrm{C}_{2} \mathrm{H}_{4} \mathrm{O}_{2}+\mathrm{O}_{2}+\mathrm{H}_{2} \mathrm{O}$ & $12 \%$ \\
\hline $\mathrm{CO}_{2}$ and $\mathrm{H}_{2} \mathrm{O}$ formation: & \\
\hline $\mathrm{C}_{3} \mathrm{H}_{6}+\frac{9}{2} \mathrm{O}_{2} \rightarrow 3 \mathrm{O}_{2}+3 \mathrm{H}_{2} \mathrm{O}$ & $3 \%$ \\
\hline
\end{tabular}

Table 3. Chemical reaction taking place at Reactor 2.

\begin{tabular}{|l|c|}
\hline \multicolumn{1}{|c|}{ Reaction } & Extent \\
\hline Acrylic acid formation: & $85 \%$ \\
$2 \mathrm{C}_{3} \mathrm{H}_{4} \mathrm{O}+\mathrm{O}_{2} \rightarrow 2 \mathrm{C}_{3} \mathrm{H}_{4} \mathrm{O}_{2}$ & \\
\hline
\end{tabular}

\section{Reactions involved}

Tables 2 and 3 show the chemical reactions involved in both Reactors [3, 18-19]:

\section{Thermodynamic package selected}

Thermodynamic model UNIQUAC/UNIFAC contained in the ChemCAD ${ }^{\circledR}$ simulator was selected to carry out vapor/liquid and vapor/liquid/liquid simulation tasks in all the process equipment except for the acids column, at which the NRTL thermodynamic model was selected. This was done taking into account the technical suggestions provided by the own simulator; the physical-chemical properties of the chemicals handled; as well as the temperature and pressure values applied all over the production process.

\section{Sensitivity studies}

Two sensitivity studies will be carried out by using the tool "Sensitivity Study" contained in the ChemCAD ${ }^{\circledR}$ simulator. The first one will evaluate the influence of absorption tower operating temperature in the amount of
AA obtained at the column bottom stream, by applying a temperature range from 20 to $60^{\circ} \mathrm{C}$. In the second study, the influence of the recovery column working pressure on the quantity of acetic acid to obtain on this equipment will be assessed. In this case, the applied range for this parameter oscillated from 0.1 to 5 bar.

\section{RESULTS AND DISCUSSIONS}

The main results obtained during process simulation regarding material and energy balances, main streams quantification, equipment performance variables, as well as sensitivity study conclusions, are shown below.

\section{Process streams}

Table 4 shows the amount of each chemical component, as well as the temperature, pressure and vapor fraction of each process stream.

According to the results shown in Table 4, the Reactor 1 exit stream $\left(\mathrm{N}^{\circ} 7\right.$ in Figure 1) presents about 8.28 $\%$ (mass basis: $\mathrm{m} / \mathrm{m}$ ) of acrolein, while the most abundant components contained on this stream are the nitrogen $(49.15 \% \mathrm{~m} / \mathrm{m})$ and water $(33.38$ $\% \mathrm{~m} / \mathrm{m}$ ). (Note: From now on all the percentage concentrations showed in this article are considered on a mass basis, that is: $\% \mathrm{~m} / \mathrm{m}$ ).

On the other hand, the Reactor 2 exit stream contains about $9.86 \%$ of AA, as well as some traces of acetic acid (1.35\%) and acrolein (1.27\%), being the components nitrogen and water again the most present on it, with $49.15 \%$ and $33.38 \%$ respectively.

The removal percentages achieved in the absorption tower for the main gaseous components are the following: oxygen $(99.99 \%)$, nitrogen $(99.99 \%)$, carbon dioxide (99.975\%), propylene $(89.82 \%)$, water $(5.21 \%)$, acetic acid (2.37\%) and AA $(2.09 \%)$. That is, this column removes effectively the noncondensable gases contained in the feed stream $\left(\mathrm{N}^{\circ}\right.$ 13), whereas there are no significant losses of the most important chemicals considered (acetic acid and AA), which are recovered at a high percentage at the bottom stream of this equipment $\left(\mathrm{N}^{\circ} 12\right)$. 


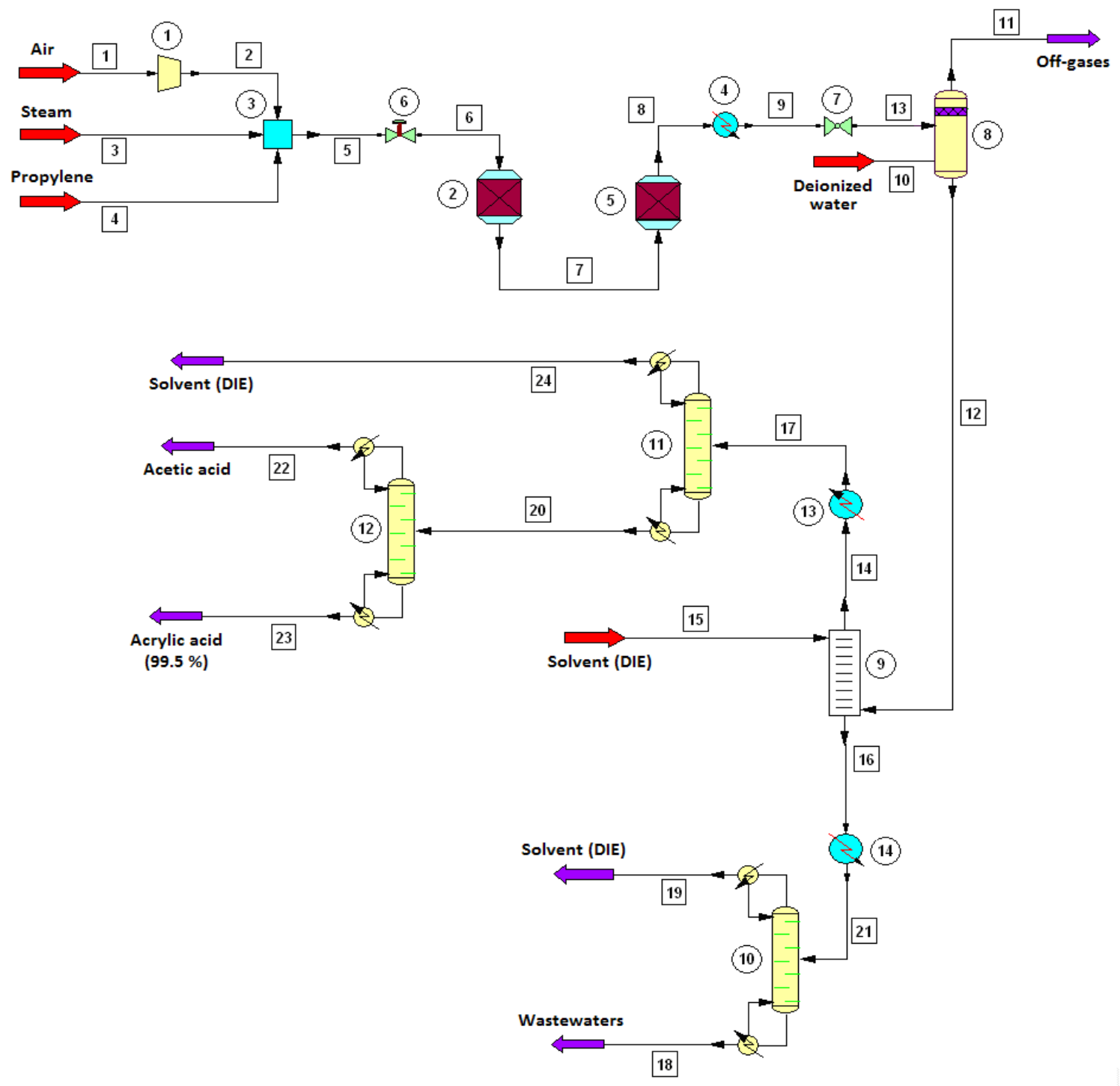

Figure 1. Production process flow diagram obtained by ChemCAD $^{\circledR}$ simulator.

Table 4. Results obtained for the main process streams.

\begin{tabular}{|l|c|c|c|c|c|c|c|}
\hline \multirow{2}{*}{ Variable } & \multicolumn{7}{c|}{ Stream number (refer to Fig. 1) } \\
\cline { 2 - 10 } & $\mathbf{5}$ & $\mathbf{7}$ & $\mathbf{8}$ & $\mathbf{1 1}$ & $\mathbf{1 2}$ & $\mathbf{1 7}$ & $\mathbf{2 0}$ \\
\hline Temperature $\left({ }^{\circ} \mathrm{C}\right)$ & 194.29 & 300 & 300 & 60 & 60 & 85 & 64.8 \\
\hline Pressure (bar) & 6 & 2.6 & 2.6 & 4 & 4 & 2.8 & 0.25 \\
\hline Vapor fraction & 1 & 1 & 1 & 1 & 0 & 0 & 0 \\
\hline
\end{tabular}




\begin{tabular}{|c|c|c|c|c|c|c|c|}
\hline \multirow{2}{*}{$\begin{array}{l}\text { Chemical } \\
\text { Propylene }\end{array}$} & \multicolumn{7}{|c|}{ Flowrate $[\mathrm{kg} / \mathrm{h}]$} \\
\hline & 5000.00 & 50.000 & 50.000 & 44.912 & 5.088 & 4.543 & 0.0075 \\
\hline Carbon dioxide & - & 941.256 & 941.256 & 941.027 & 0.229 & 0.204 & $2.42 * 10^{-7}$ \\
\hline Water & 19000.00 & 21204.730 & 21204.730 & 1104.740 & 22639.980 & 20308.070 & 18922.850 \\
\hline Acrolein & - & 5262.537 & 789.280 & 605.865 & 183.515 & 163.566 & 17.795 \\
\hline Acetic acid & - & 856.249 & 856.249 & 20.299 & 835.949 & 747.142 & 746.379 \\
\hline Acrylic acid & - & 513.752 & 6263.494 & 131.177 & 6132.317 & 5475.456 & 5469.980 \\
\hline Oxygen & 8300.60 & 3471.427 & 2194.882 & 2194.765 & 0.117 & 0.105 & - \\
\hline Nitrogen & 31224.04 & 31224.040 & 31224.040 & 31223.260 & 0.783 & 0.701 & - \\
\hline Di-isopropylether & - & - & - & - & - & 490.272 & 4.903 \\
\hline Total & 63524.64 & 63523.991 & 63523.931 & 36266.045 & 29797.978 & 27190.059 & 25161.914 \\
\hline \multirow{2}{*}{ Variable } & \multicolumn{6}{|c|}{ Stream number (refer to Fig. 1) } & \\
\hline & 24 & 22 & 23 & 18 & 19 & 21 & \\
\hline Temperature $\left({ }^{\circ} \mathrm{C}\right)$ & 78.14 & 46.04 & 87.80 & 138.72 & 132.252 & 95 & \\
\hline Pressure (bar) & 0.15 & 0.1 & 0.15 & 3.5 & 3 & 2.8 & \\
\hline Vapor fraction & 1 & 1 & 0 & 0 & 1 & 0 & \\
\hline Chemical & \multicolumn{6}{|c|}{ Flowrate $[\mathrm{kg} / \mathrm{h}]$} & \\
\hline Propylene & 4.535 & 0.0075 & - & 0.154 & 0.391 & 0.545 & \\
\hline Carbon dioxide & 0.204 & $2,42 * 10^{-7}$ & - & $8.645 * 10^{-5}$ & 0.024 & 0.024 & \\
\hline Water & 1385.228 & $18922 ., 850$ & - & 2215.314 & 116.595 & 2331.910 & \\
\hline Acrolein & 145.771 & 17.795 & - & 5.422 & 14.527 & 19.949 & \\
\hline Acetic acid & 0.763 & 738.915 & 7.464 & 86.174 & 2.633 & 88.808 & \\
\hline Acrylic acid & 5.476 & 5.469 & 5464.510 & 633.654 & 23.207 & 656.862 & \\
\hline Oxygen & 0.105 & - & - & $9.699 * 10^{-7}$ & 0.012 & 0.012 & \\
\hline Nitrogen & 0.701 & - & - & $4.136 * 10^{-6}$ & 0.082 & 0.082 & \\
\hline Di-isopropylether & 485.369 & 4.903 & - & 0.486 & 9.241 & 9.728 & \\
\hline Total & 2028.152 & 19689.9395 & 5471.974 & 2941.206 & 166.712 & 3107.920 & \\
\hline
\end{tabular}

The extractor extracts the AA and acetic acid with an extraction efficiency of $89.29 \%$ and $89.37 \%$, respectively, that is, the losses of both components in this equipment are of $10.71 \%$ and $10.63 \%$, respectively. The main components obtained at the extractor top stream are water (74.69\%), AA (20.14\%) and acetic acid $(2.75 \%)$. The recovery column (recuperator) purifies both the AA and acetic acid in $99.90 \%$, while the DIE solvent is recovered in $99.01 \%$. Water is removed in $6.82 \%$, while both AA and acetic acid are obtained at the bottom stream (No. 20 ), at the following mass percentages: $21.74 \%$ and $2.97 \%$, respectively, being the water the component most present on this stream, sharing $75.20 \%$ of the total flow. Taking into account the results displayed for the recuperator, we concluded that this equipment works efficiently regarding the removal percentage obtained for the solvent DIE, which is very high ( $99 \%$ ), while there aren't significant losses of the two main components considered (AA and acetic acid) on the top stream (No. 24).

The bottom stream of the acids column $\left(\mathrm{N}^{\circ} 23\right)$ contains the main product (AA) with $99.86 \%$ of purity, being the main impurities found on it the acetic acid $(0.078 \%)$ and water $(0.092 \%)$. In that case, both the water and acetic acid fed to this column are removed with $99 \%$ removal efficiency. The acids column top stream $\left(\mathrm{N}^{\circ} 22\right)$ contains mostly water $(96.10 \%)$ and acetic acid $(3.75 \%)$, and also about $5.5 \mathrm{~kg}$ of AA. It should be considered to install additional separation equipment (distillation column) to process the top stream of the acids column, in order to recover and purify about $730 \mathrm{~kg}$ of acetic acid contained on it, to be subsequently commercialized as a byproduct.

Finally, the top stream obtained in the residuals column $\left(\mathrm{N}^{\circ} 19\right)$ contains mostly water $(69.94 \%)$, 
Equipment operating parameters: Compressor (Equipment $N^{\circ} 1$ in Figure 1):

\begin{tabular}{|l|c|}
\hline \multicolumn{1}{|c|}{ Parameter } & Value \\
\hline $\mathrm{Cp} / \mathrm{Cv}$ (ideal) & 1.39903 \\
\hline $\mathrm{Cp} / \mathrm{Cv}$ (real) & 1.40039 \\
\hline Energy consumption (theoretical) $[\mathrm{kW}]$ & 22.15 \\
\hline Energy consumption (real) $[\mathrm{kW}]$ & 27.37 \\
\hline
\end{tabular}

\section{Heat exchangers:}

\begin{tabular}{|l|c|c|c|}
\hline \multicolumn{1}{|c|}{ Parameter } & $\mathbf{1}(\mathbf{4})$ & $\mathbf{2}(\mathbf{1 3})$ & $\mathbf{3}(\mathbf{1 4})$ \\
\hline $\begin{array}{l}\text { Calculated heat duty } \\
{[\mathrm{MJ} / \mathrm{h}]}\end{array}$ & -66440.8 & 2545.51 & 404.075 \\
\hline
\end{tabular}

\section{Extractor (9):}

\begin{tabular}{|l|c|}
\hline \multicolumn{1}{|c|}{ Parameter } & Value \\
\hline Number of stages & 16 \\
\hline Murphree efficiency (top) & 0.18 \\
\hline Murphree efficiency (bottom) & 0.07 \\
\hline
\end{tabular}

\section{Distillation columns:}

\begin{tabular}{|l|c|c|c|}
\hline \multicolumn{1}{|c|}{ Parameter } & $\begin{array}{c}\text { Residuals } \\
\text { column (10) }\end{array}$ & $\begin{array}{c}\text { Recovery } \\
\text { column } \\
\text { (11) }\end{array}$ & $\begin{array}{c}\text { Acids } \\
\text { column } \\
\text { (12) }\end{array}$ \\
\hline $\begin{array}{l}\text { Overall number of } \\
\text { stages }\end{array}$ & 43 & 18 & 32 \\
\hline Feed stage & 21 & 7 & 19 \\
\hline $\begin{array}{l}\text { Condenser heat } \\
\text { duty [MJ/h] }\end{array}$ & -26.356 & -1.250 & -18.470 \\
\hline $\begin{array}{l}\text { Reboiler heat duty } \\
\text { [MJ/h] }\end{array}$ & 788.354 & 121.934 & 229.042 \\
\hline $\begin{array}{l}\text { Reflux rate } \\
\text { (calculated) }\end{array}$ & 0.88 & 3.17 & 4.01 \\
\hline
\end{tabular}

AA (13.92\%), acrolein (8.71\%) and the solvent DIE (5.54\%), while the bottom stream $\left(\mathrm{N}^{\circ} 18\right)$ contains essentially water $(75.32 \%)$ and AA (21.54\%). The solvent DIE is recovered in this column at $95 \%$ of recovery efficiency. It's suggested to install an additional recovery step to recuperate the important amounts of AA contained at this bottom stream ( $630 \mathrm{~kg}$ ), in order to increase the profitability and productivity of the overall production process.

Accordingly, the amount of each raw material consumed per $\mathrm{kg}$ of AA produced (i.e. the unit consumption index) can be obtained for the overall production process, which is:

- Air: $7.22 \mathrm{~kg} / \mathrm{kg}$ AA.

- $\quad$ Steam: $3.47 \mathrm{~kg} / \mathrm{kg}$ AA.

- Propylene: $0.914 \mathrm{~kg} / \mathrm{kg}$ AA.
Giving the results obtained for each equipment involved in the production process, it can be observed that the total reaction heat calculated for the Reactor $\mathrm{N}^{\circ} 1$ is about $7410000 \mathrm{MJ} / \mathrm{h}$ higher than that determined for the Reactor $\mathrm{N}^{\circ} 2$. This is directly related with the number of reactions taking place in the first reactor (4 reactions) regarding the only one carried out in the second reactor (that is, the formation of acrolein). In this case, the higher the number of reactions involved, higher will be the heat released. It also means that the Reactor 1 will need a higher flow of refrigerant to maintain the reaction temperature under the required limits, and important decisions should be taken related with the selection of proper construction materials and the optimum wall thickness. Regarding heat exchangers results, the first one used have the higher heat duty of all since here is where the temperature of the hot gaseous mixture exiting the Reactor 2 is reduced from $300{ }^{\circ} \mathrm{C}$ to $70{ }^{\circ} \mathrm{C}\left(230^{\circ} \mathrm{C}\right.$ of reduction), which originates an important release of heat by the material being cooled.

Considering the Murphree efficiency results at the extractor, the top section (enrichment) deviates from the ideal efficiency about $18 \%$, while the bottom section (depletion) deviates about 7\%, which confirms that this equipment operates close to the ideal efficiency values in both sections. This equipment will need about 16 stages (or plates) to obtain the required separation extent.

Finally, regarding results obtained for the distillation columns, the column that needs the higher amount of stages (plates) is the residuals column, since there is where the solvent DIE is separated and purified from the rest of the components. Since the DIE should be recovered at a high percentage (95\% minimum) in this equipment due to economic issues, this implicates that as may stages as possible should be needed to face this elevated separation requisite. Moreover, a liquid stream containing almost all the chemicals used throughout the production process is fed to this equipment, which increases the specificity, selectivity and complexity of this distillation separation process. The recovery column, on the other hand, has a minor amount of stages (18 stages) since it is where the solvent DIE is separated from the acetic acid and AA, which constitutes a relatively simple distillation operation due to the significant boiling point differences existing among those chemicals, as 


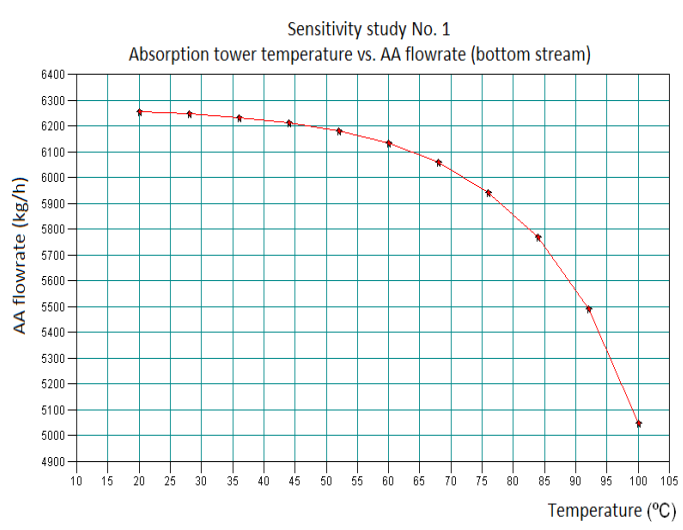

a)

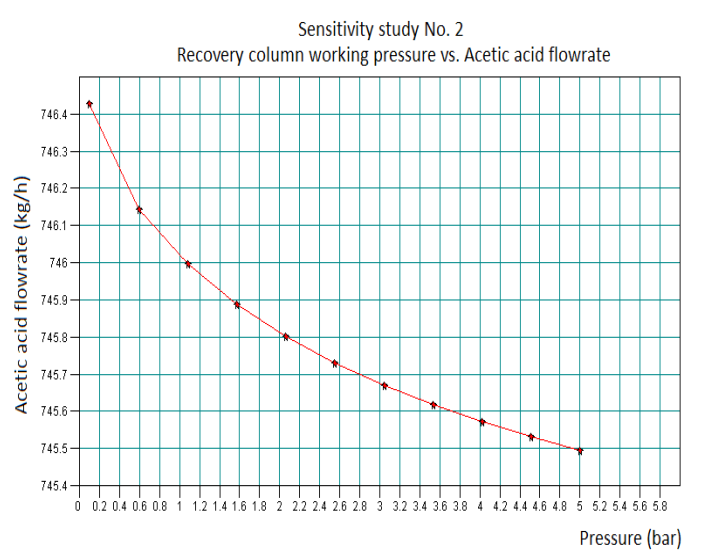

b)

Figure 2. Sensitivity studies results using ChemCAD ${ }^{\circledR}$ simulator.

a) Absorption tower temperature vs. AA flowrate at absorption tower bottom stream.

b) Recovery column working pressure vs. Acetic acid flowrate.

well as due to the small amount of other compounds (impurities) contained at the feed stream $\left(\mathrm{N}^{\circ} 17\right)$.

\section{Sensitivity studies}

Figure 2 shows the results obtained for both sensitivity studies carried out. In the Sensitivity Study $\mathrm{N}^{\circ} 1$ [Figure 2a)], an increment of the absorption tower operating temperature will bring about a reduction of the AA amount to obtain at the bottom stream. This is due, fundamentally, to an increment in the evaporation of this compound at the top of this equipment. The shape of the curve shown in the Figure 2a) suggests that as long as the temperature range increments, higher amounts of AA will be obtained at the top of the equipment. In that case, a temperature increment from $20^{\circ} \mathrm{C}$ to $60^{\circ} \mathrm{C}$ will cause AA loses of about $100 \mathrm{~kg} / \mathrm{h}$, while an increment from $60{ }^{\circ} \mathrm{C}$ to $100^{\circ} \mathrm{C}$ will cause $1100 \mathrm{~kg} / \mathrm{h}$ of AA loses, approximately. So, in order to minimize AA loses it's necessary that the absorption tower operates at a temperature near $20^{\circ} \mathrm{C}$.

Taking into account the results achieved in the Sensitivity Study $\mathrm{N}^{\circ} 2$ [Figure 2b)], an increment in the recovery column working pressure will lead to a reduction in the amount of acetic acid to obtain at the bottom stream. Considering that, if the column pressure is incremented from 0.1 to $2.5 \mathrm{bar}$, acetic acid loses of about $0.75 \mathrm{~kg} / \mathrm{h}$ will be obtained, while if exists a pressure increment from 2.5 to 5.0 bar, the loses will be $0.21 \mathrm{~kg} / \mathrm{h}$. These results support the previously exposed requirement at where it's suggested to operate all the distillation columns at the lowest pressure possible, preferably under vacuum conditions, to avoid significant product loses as well as AA dimerization. It's recommended then to operate the recovery column under vacuum conditions.

\section{CONCLUSIONS}

About $7.22 \mathrm{~kg}$ of air; $3.47 \mathrm{~kg}$ of steam and $0.914 \mathrm{~kg}$ of propylene are required to produce 1 kilogram of glacial-grade acrylic acid (purity: 98-99,5\%), using the gaseous propylene catalytic oxidation route.

It's recommended that the absorption tower operates at a temperature closest to $20^{\circ} \mathrm{C}$.

The recovery column must operate preferably under vacuum conditions in order to minimize both the AA and acetic acid loses at the bottom stream.

The extractor absorbs the AA and acetic acid with an absorption efficiency of $89.29 \%$ and $89.37 \%$, respectively.

Both the AA and acetic acid are purified in the recovery column at $99.90 \%$, while the solvent DIE is recovered at $99.01 \%$. 


\section{REFERENCES}

[1] D. Mackay, W.Y. Shiu, K.C. Ma and S.C. Lee. "Handbook of Physical-Chemical Properties and Environmental Fate for Organic Chemicals". CRC Press, Taylor \& Francis Group. Ed. 2. Boca Raton. Florida, USA. Vol. III: Oxygen Containing Compounds. pp. 2718-2720. 2006. ISBN: 1-56670-687-4.

[2] J.G. Speight. "Chemical and process design handbook". McGraw-Hill. New York, NY, USA. pp. 2.25-2.26. 2002. ISBN: 0-07-137433-7.

[3] WVU. ChE 183-Design of a New Facility to Produce Polymer-Grade Acrylic Acid. 2012. Fecha de Consulta: 15 de junio, 2016. URL: http://www. che.cemr.wvu.edu/publications/projects.html.

[4] U. Diwekar. "Green Process Design, Industrial Ecology, and Sustainability: A Systems Analysis Perspective". Resources, Conservation and Recycling. Vol. 44, pp. 215-235. 2005. DOI: 10.1016/j.resconrec.2005.01.007.

[5] N. A. Auli, M. Sakinah, A. Bakri, H. Kamarudin and M. N. Norazian. "Simulation Of Xylitol Production: A Review". Australian Journal of Basic and Applied Sciences. Vol. 7, Issue 5, pp. 366-372. 2013. ISSN: 1991-8178.

[6] A. Dimian and C. Sorin. "Chemical process design: Computer-aided case studies". WILEY-VCH Verlag GmbH \& Co. KGaA. Weinheim, Germany, pp. 84-102. 2008. ISBN: 978-3-527-31403-4.

[7] R. Turton, R. C. Bailie, W. B. Whiting, J. A. Shaeiwitz and D. Bhattacharyya. "Analysis, Synthesis, and Design of Chemical Processes". Prentice Hall. Ed. 4. Ann Arbor. Michigan, USA. pp. 6-32. 2012. ISBN: 978-0-13-261812-0.

[8] J. Eliasson. "Design of an Plant for Manufacturing of Acetaldehyde". Department of Chemical Engineering, Lund University. Lund, Sweden. pp. 1-4. 2010.

[9] E. Benanti, C. Freda, V. Lorefice, G. Braccio and V. K. Sharma. "Simulation of Olive Pits Pyrolysis in a Rotary Kiln Plant". Thermal Science. Vol. 15 Issue 1, pp. 145-158. 2011. DOI: 10.2298/TSCI090901073B.

[10] C. Chilev and E. Simeonov. "Simulation of Biodiesel Production by Transesterification of Vegetable Oils". Journal of Chemical Technology and Metallurgy. Vol. 49 Issue 5, pp. 479-486. 2014.
[11] D. Otte, H. M. Lorenz and J. U. Repke. "A toolbox using the stochastic optimization algorithm MIPT and ChemCAD for the systematic process retrofit of complex chemical processes". Computers and Chemical Engineering. Vol. 84, pp. 371-381. 2016. DOI: http://dx.doi. org/10.1016/j.compchemeng.2015.08.023.

[12] A. Bader, S. Bauersfeld, C. Brunhuber, R. Pardemann and B. Meyer. "Modelling of a Chemical Reactor for Simulation of a Methanisation Plant". Department of Energy Process Engineering and Chemical Engineering, Technische Universität Bergakademie. Freiberg, Germany, pp. 1-7. 2012.

[13] A. Sarwar. "Plant Design for the Separation of Various Components from Turpentine Oil". Master of Science Thesis, Department of Chemical and Biological Engineering, Chalmers University of Technology. Göteborg. Sweden, pp. 12-35. 2012.

[14] T. Johansen, A. Johnsen and I. Christiansen. "A Comparison of Training Simulators for the Formox Process". Department of Chemical Engineering. Faculty of Natural Sciences and Technology, Norwegian University of Science and Technology. Norway, pp. 26-68. 2013.

[15] G. Towler and R. Sinnot. "Chemical Engineering Design-Principles. Practice and Economics of Plant and Process Design". ButterworthHeinemann. San Diego. California, USA. pp. 1-48. 2008. ISBN: 978-0-7506-8423-1.

[16] C. Boyadjiev. "Theoretical Chemical Engineering. Modeling and Simulation". Springer-Verlag. Berlin, Germany. pp. 553-570. 2010. ISBN: 978-3-642-10777-1.

[17] T.V. Andrushkevich. "Heterogeneous Catalytic Oxidation of Acrolein to Acrylic Acid: Mechanism and Catalysts". Catalysis Reviews: Science and Engineering. Vol. 35 Issue 2, pp. 213-259. 1993. DOI: http://dx.doi. org/10.1080/01614949308014606

[18] H. Fansuri. "Catalytic Partial Oxidation of Propylene to Acrolein: The Catalyst Structure, Reaction Mechanisms and Kinetics". (PhD Thesis), Department of Chemical Engineering, Centre for Fuels and Energy. Curtin University of Technology. Australia. pp. $112-119.2005$.

[19] S.A. Setyowati. "Catalytic Partial Oxidation of Propylene for Acrolein Production". (Master of Philosophy Thesis). Department of Chemical Engineering, Curtin University. Australia. pp. 10-21. 2011. 